\title{
NEW STUDIES IN SOCIOLOGY
}

This series, prepared under the auspices of the British Sociological Association, has now been revised to present larger, more substantial works. The overall purpose of the series remains the same: to provide scholarly yet argumentative treatments of key problems in sociology. The books are neither textbooks nor research monographs. Rather they present an original viewpoint upon subjects where an orthodoxy does not exist, whether because of undue neglect or because recent research has overturned previous orthodoxies. The series is designed to provide empirically informed theory about society, relating a diversity of empirical areas to central problems of sociological theory. 


\section{NEW STUDIES IN SOCIOLOGY}

Published in conjunction with the

British Sociological Association

Editor: Michael Mann

Published

Ideas about Illness: An Intellectual and Political History of Medical Sociology

Uta Gerhardt

The Transition from Feudalism to Capitalism

Bob Holton

Politics in the Semi-Periphery: Early Parliamentarianism and Late Industrialisation in the Balkans and Latin America

Nicos P. Mouzelis

Calvinism and the Capitalist Spirit: Max Weber's Protestant Ethic Gianfranco Poggi

\section{Series Standing Order}

If you would like to receive future titles in this series as they are published, you can make use of our standing order facility. To place a standing order please contact your bookseller or, in case of difficulty, write to us at the address below with your name and address and the name of the series. Please state with which title you wish to begin your standing order. (If you live outside the United Kingdom we may not have the rights for your area, in which case we will forward your order to the publisher concerned.)

Customer Services Department, Macmillan Distribution Ltd Houndmills, Basingstoke, Hampshire, RG21 2XS, England. 


\section{Ideas about Illness}

An Intellectual and Political History of Medical Sociology

Uta Gerhardt 


\section{(C) Uta Gerhardt 1989}

All rights reserved. No reproduction, copy or transmission of this publication may be made without written permission.

No paragraph of this publication may be reproduced, copied or transmitted save with written permission or in accordance with the provisions of the Copyright Act 1956 (as amended), or under the terms of any license permitting limited copying issued by the Copyright Licensing Agency, 33-4 Alfred Place, London WC1E 7DP.

Any person who does any unauthorised act in relation to this publication may be liable to criminal prosecution and civil claims for damages.

First published 1989

Published by

MACMILLAN EDUCATION LTD

Houndmills, Basingstoke, Hampshire RG21 2XS

and London

Companies and representatives

throughout the world

\section{British Library Cataloguing in Publication Data}

Gerhardt, Uta E.

Ideas about illness: an intellectual and political history of medical sociology. -

(New studies in sociology)

1. Sociology of medicine, 1987

I. Title II. Series

$306^{\prime} .46$

ISBN 978-0-333-24869-0

ISBN 978-1-349-20016-0 (eBook)

DOI 10.1007/978-1-349-20016-0 


\section{Contents}

Preface ix

Introduction: The Origin of Medical Sociology xi

Part I

THE STRUCTURAL-FUNCTIONALIST PARADIGM:

ILLNESS AS SOCIAL ROLE AND MOTIVATED

DEVIANCE

Talcott Parsons' Theory of Social Systems Introduction: The Structural-Functional Pledge

1 Parsons' Notion of Illness 5

The Dual Nature of Illness $\quad 8$

Relativism as a Political Answer $\quad 10$

Two Models of Illness 14

2 The Capacity Model 16

The Three Stages of Aetiology 17

The Normality Stage 17

'Vicious Circles' and the Exhaustion of Exchange 20

The State of Illness 21

Therapy and the Doctor-Patient Interaction 23

Identification of Treatment and Sick-Role
Incumbency

The Doctor-Patient System 26

The Question of Chronic Illness 32

3 The Deviancy Model 34

The Three Stages of Aetiology 37

The Normality Stage 37

The Crisis of Cathexis 41

The State of Illness 46

Therapy and the Treatment Process 48

Identification of Therapy and Social Control 48 
'Unconscious Psychotherapy' 52

The Undercurrent of Presumptive Deviance 56

4 Structural-Functionalist Systems Theory and the Two Models of Illness

The Two Models Revisited 60

The Contribution to General Sociological Theory 64

The Place of Psychiatry

THE INTERACTIONIST PARADIGM: ILLNESS AS PROFESSIONAL CONSTRUCTION

Labelling Approach, Anti-Psychiatry and

'Grounded Theory'

Introduction: The Anti-Parsonian Impetus

5 The Interactionist Notion of Illness

The Dual Nature of Illness

The Political Message of Relativism $\quad 84$

Two Models of Illness $\quad 89$

6 The Crisis Model 91

The Three Stages of Aetiology 92

The State of Normality 92

The 'Societal Reaction' 99

The State of Illness or Disability 106

Therapy or the Impact of Institutions 111

Identification of Treatment and Treatment

Ideologies

The Iatrogenic Effect of the Treatment and/or

Institution

The Undercurrent of Presumptive Normality

7 The Negotiation Model

The Three Stages of Aetiology 127

Normality as Uncertainty 127

Diagnosis 132

Chronic Illness: Management and Self 138

Therapy and the Management of Treatment 142

The Social Construction of Hospital Treatment 143

Coping in Everyday Life 149

The Problem of Acute Illness 154 
8 'Symbolic Interactionism' and the Two Models of Illness

The Two Models Revisited

The Contribution to General Sociological Theory

The Place of Pathology

Part III

THE PHENOMENOLOGICAL PARADIGM:

ILLNESS AS INTERSUBJECTIVELY CONSTRUCTED REALITY

Ethnomethodology, Cognitive Sociology and Conversational Analysis

Introduction: The Weberian Legacy

9 The Phenomenological Notion of Illness

The Dual Nature of Illness

The Issue of Political Impact

One Model of Illness

10 The Trouble Model

The Three Steps of Aetiology

The Normality Stage

Cycles of Help

The State of Illness (Disability)

Therapy and Clinical Practice

Organisational Routines and Normal Illness

216

The Form and Function of Medical Talk

217

The Purpose of Medical Practice

223

225

11 Phenomenology and the Issues of Responsibility 229

On the Question of Model(s)

The Contribution to General Sociological Theory

234

The Place of Criminology

242

Part IV

THE CONFLICT-THEORY PARADIGM: ILLNESS AS FAILURE OF RESOURCES AND IDEOLOGICAL CONSTRUCT

Life-Change Research, Social Constructionism, and Political Economy of Health

Introduction: Medical Sociology has Come of Age 
12 The Conflict Notion of Illness 259

The Double Nature of Illness 264

The Medicalisation of Politics and the Politicisation of Medicine

Two Models of Illness

13 The Loss Model

The Three Stages of Aetiology 278

The Normality Stage 278

Falling Ill and Seeking Help 285

Disability and Support 292

Therapy and the Self-Care of Patients 295

Redefining Primary Care 296

The New Role of the Welfare State 298

The Purpose of Patient Advocacy 302

14 The Domination-Deprivation Model 308

The Three Stages of Aetiology 316

The Production of Ill Health 316

The Meaning of Medical Practice 318

The Sickness of Society 320

Therapy and the Change of Society 322

Replacing Clinical Practice by Ecological

Medicine $\quad 324$

Redirecting Social Policy 329

Individualism versus Collectivism 331

15 Conflict Theory and the Two Models of Illness 335

The Two Models Revisited 337

The Contribution to General Sociological Theory $\quad 340$

The Place of Sociology 348

Epilogue: The Future of Medical Sociology 352

Notes $\quad 355$

References 361

Name Index $\quad 407$

Subject Index $\quad 000$ 


\section{Preface}

This book on the history of ideas of medical sociology has itself a history of attempt, abandonment, and eventual breakthrough. It first took shape in my mind in the mid-1970s. I felt that my students at London University's (Bedford College) Social Research Unit's MSc. course, 'Sociology as Applied to Medicine', would benefit from an overview of sociology's conceptualisation of illness. After this had led to a couple of lectures, and then the plan of a short book, I began to realise that this was a major undertaking. In 1977, I submitted a synopsis to Macmillan (through Michael Mann who accepted the book for the series he edited, New Studies in Sociology). In 1980, after I had taken up a professorship in my native Germany, Dr Mann and I realised that the book was becoming much too long for the series. Since I felt this to be unavoidable, I eventually decided to abandon the manuscript (half regretfully, half relieved). In 1984, a new general editor at Macmillan asked me whether I could revive the project, offering some freedom as regards the scope of the book. Again, Dr Mann gave me wholehearted encouragement. Eventually the book was finished with valuable help from the libraries at the British $\mathrm{Mu}$ seum, the London School of Economics and Harvard University, and with invaluable help from colleagues and friends willing to discuss my ideas with both fervour and rigour.

Above all, I wish to thank Nicky Hart for reading large parts of the manuscript and advising me in unselfish painstaking detail on both content and style. Over the years, among those colleagues and friends commenting on chapters or ideas have been David Armstrong, Susan Bell, Cathy Charmaz, Eliot Freidson, James Greenley, Joan McCord, Hans-Peter Müller, Cathy Riessman, Günther Roth, Hans-Georg Soeffner, Anselm Strauss and Michael Wadsworth, to name but a few. Of course, the book's mistakes and shortcomings are my own. But many of its interpretations would not have become crystallised without my discussion partners' patience and resourcefulness. Also, the typing by Jutta Kreiling and Doris Turner of various versions of various chapters is gratefully acknowledged. 


\section{x Preface}

Last but not least, without the unfailing affection of my daughter, Agnes, I would have been in danger of becoming too obsessed with my work. Her love and friendship were strong enough to make me feel that it is all worthwhile.

UTA GERHARDT 


\section{Introduction: The Origin of Medical Sociology}

Max Weber identified the essence of sociology as social action represented by types of legitimate authority. In this he ignored the mundane fact that physical or mental health is necessary if actors are to take part in subjective reciprocal meaning formation. Equally, he does not discuss the fact that the claim to authority or loyalty in asymmetrical relationships might be conditional upon the physical or mental health of the powerful.

In Emile Durkheim's Suicide (1897/1952), no mention is made of psychiatric categories when rates are attributed to the pathological state of society as a whole. In the social limbo between the abandonment of mechanical solidarity and the stunted emergence of organic solidarity, Durkheim regarded as improper terrain for sociology a view which relates the ills of present-day society to the physical or mental state of its members.

It might have sounded absurd had Marx made provision in the analysis of class struggle for the representatives of capital and labour to be mentally or physically fit. Of course, doctors in Marx's time were not what they are today. But in no way would Marx have identified the wrongs of capitalist society with the power which doctors acted out over their patients. Their right (or nerve) to define or refuse treatment was no topic for the critique of political economics.

For Herbert Spencer, the evolution from tribal to modern society was never connected with variations of the physical or mental make-up of the individual members of society. Rather, medical metaphors were used to explain the workings of society as a whole, and the 'sociological division of labour' seemed but an extension of the 'physiological division of labour' as is demonstrated by the following (rather lengthy) quote from The Principles of Sociology:

we see the parts of the alimentary canal performing their functions one after another. There come in succession mastication, insalivation, deglutition, trituration, chymification, chylification, and eventually 


\section{xii Introduction: The Origin of Medical Sociology}

absorption by the lacteals. And here indeed it is curious to remark a unique case in which two sets of sociological division of labour of the serial kind, are joined to this physiological series of divisions of labour. We have first the ploughing, harrowing, sowing, reaping, carting, threshing, hauling to market, transfer to corn factor's stores, removal thence to be ground, and final carriage of the flour to the bakers; where, also, certain serial processes are gone through in making loaves ... . or . . . biscuits ... Finally, in one who eats the loaves or the biscuits, there occurs the physiological series of division of labour. So that from the ploughing to the absorption of nutriment, three series of divisions of labour become, in a sense, parts of a united series. (Spencer, 1876, pp. 661-2).

This example of body-society folklore epitomises how remote in nineteenth century sociology was the idea that a person's normal organic or mental functioning was not to be taken for granted. Equally remote was the idea that medicine or medical practice might be seen as a social institution with integrative functions for society.

While Spencer and, to a certain extent, Durkheim used a structural analogy between society and physiology to explain the functioning of the social order, other authors referred to the body or mind to explain individuation in society. For instance, from the vast array of social formations taken from the documented history of Western civilisation, Simmel failed to draw upon health or medical practice as a subject of sociological enquiry. This is despite the fact that several of the exkurse $e^{1}$ appearing in Simmel's Sociology (1908) focused upon issues of bodily conduct. For example, a rudimentary sociology of the senses was outlined, with special reference to the distinctive cultural meaning of olfactory versus visual stimuli.

Similarly, Norbert Elias' Process of Civilisation (first published in 1939) focused upon the social meaning and stylisation of body parts and processes (such as, for example, eating, burping, farting or defecating, and the rules of politely treating someone thus engaged temporarily as a non-person). But Elias failed to extend the topic to include failures of bodily (or mental) functioning. Thus he abstained from analysing the norms of deference and demeanour which signify and regulate the conduct of the ablebodied and the sane. Rather, Elias concentrated on the rules and regulations which define proper conduct, say, in the presence of ladies, or of superiors, between the sexes or between persons of different social ranking, and so on. Not even for the late nineteenth and early twentieth centuries, the most contemporary periods of his investigations, would Elias identify the explicitly hygienic nature of the then fashionable accounts or justifications of such 
centuries-old rules as that one should not eat from the same plate, let alone spoon, as another person. By confining himself to the published literature on etiquette and leaving out everydaylanguage sources justifying the etiquette rules, Elias paints a picture of the upstairs-downstairs world of yesteryear in which no trace of health or illness appears to enter the realms of dominant mores or norms.

Thus classical sociological thought attributed little significance to the physical or mental state of the person, while problems of social organisation and structure were prominent. Health was a sociological non-issue while sociology rigorously sought to define a terrain all its own. Perhaps health was seen as an aspect of the everyday world while sociology located itself in the world of science and higher learning; or sociology may have taken health for granted because Victorian standards of decency held that 'personal' health issues did not deserve the ominous limelight of public attention, let alone the dubious focus of sociological theorising. Especially in cases where health failed, it was to be shamefully confined to the private quarters of the afflicted person's home and family or neighbourhood. In all, a pervasive distinction prevailed between 'profane' life worlds incorporating matters of physical and mental health, and the 'sacred' world of academic achievement. It made it unlikely that sociology (which placed itself in the latter) would recognise the unreality of assuming a healthy physical and mental state as characterising human beings in general. Sociology's interest in the rationalisation of the world meant that the irrational - particularly if it equalled the unhealthy remained beyond the postulated image of mankind.

What about Marx and Engels? Were they not concerned with illness and premature death in capitalist society? Sickness was exposed by them as one of the plights suffered by the exploited and disenfranchised masses whose fate depended on the state of the labour market. As Marx and Engels pointed out, sickness and subsequent death were perpetual risks implied in the insecure status of the labouring classes. Since physical strength and fitness determined the quality of one's labour power sold as a commodity on the labour market, each worker's, as well as each worker's family's, life chances depended on the state of the worker's health. Physical strength, however, was not seen as individual prowess but rather in relation to environmental conditions. Engels made it clear that it was the unhealthy aspects of work, area of residence, housing and life style which accounted for the low life expectation of workers and their families. This was in accordance with the then most up-to-date theories of medicine which related miasma 
(unclean emissions, such as smell or dirt, caused by lack of ventilation, lack of sanitation, etc.) to the incidence of illness (and possibly death), while the procurement of clean air through ventilation as well as of clear water and clean streets through sanitation were taken to promote and secure good health. Therefore, when published in 1847, Engels' Condition of the Working-Class in England provided a medically satisfactory explanation of the higher incidence of sickness in working-class communities by referring to issues of poor housing and nutrition:

That the dwellings of the workers in the worst portions of the cities, together with the other conditions of life of this class, engender numerous diseases, is attested on all sides ... That the bad air of London, and especially of the working-people's districts, is in the highest degree favourable to the development of consumption, the hectic appearance of great numbers of persons sufficiently indicates ... Typhus, that universally diffused affliction, is attributed by the official report on the sanitary conditions directly to the bad state of the dwellings in the matters of ventilation, drainage, and cleanliness ... When one... thinks how crowded their dwellings are, how every nook and corner swarms with human beings, how sick and well sleep in the same room, in the same bed, the only wonder is that a contagious disease like this does not spread yet further . . . Another category of diseases arises directly from the food rather than the dwellings of the workers. The food of the labourer, indigestible enough in itself, is utterly unfit for young children, and he has neither means nor time to get his children more suitable food. Moreover, the custom of giving children spirits, even opium, is very general; and these two influences, with the rest of the conditions of life prejudicial to bodily development, give rise to the most diverse affections of the digestive organs, leaving life-long traces on them. (Engels, 1953, pp. 131-4)

Engels cited evidence from chemistry to reinforce the idea that the bio-mechanics of illness are triggered by environmental hazards. He related lack of oxygen and surplus carbon monoxide to 'physical lassitude and low vitality' which, according to eighteenth-century medical theory, ${ }^{2}$ accounts for the exhaustion of vital energy:

Two and a half million pairs of lungs, two hundred and fifty thousand fires, crowded upon an area three to four miles square, consume an enormous amount of oxygen, which is replaced with difficulty, because the methods of building cities in itself impedes ventilation. The carbonic acid gas, engendered by respiration and fire, remains in the streets by reason of its specific gravity, and the chief air current passes over the roofs of the city. The lungs of the inhabitants fail to receive the 
due supply of oxygen, and the consequence is mental and physical lassitude and low vitality. (Engels, 1953, p. 129)

However, for Engels as for Marx, ill health and premature death (albeit suffered by individuals) were indicators of the capitalist society sui generis. Their analysis focused on the wrongs inflicted by class society upon the working class as a whole rather than its individual members. Their aim was to arouse concern or compassion in the bourgeoisie and class spirit in the proletariat. Health issues could be used to instigate revolutionary action in the hope of superseding capitalist society, but were not an essential part of the latter's conceptual analysis. The reproduction of healthy labour power was not conceptualised as an element of social theory but as a matter of living conditions to be overcome by revolutionary action. In essence, neither Marx nor Engels was interested in the question of whether the physical or mental state of an individual was sufficient to enable him or her to fulfil the duties of a normal person.

This topic was first raised in the 1930s. It followed the somewhat earlier recognition that medicine and medical practice were appropriate objects of sociological enquiry. Only after the Second World War did the view gain momentum that physical and particularly mental health are important for the social fabric.

The earliest citation of the illness issue was as a metaphor to illustrate the workings of the social system. Lawrence J. Henderson, MD, who held a chair of biological chemistry at both Harvard College and Harvard Medical School, brought together between 1932 and 1934 several eminent scholars from such diverse fields as English literature, history, economics and sociology to discuss the social systems perspective proposed by Vilfredo Pareto's General Sociology. The crucial idea was the mutual dependence of components of society. In his lecture on the topic of physician and patient as a social system (1935b), Henderson argued that since medicine is applied science, thereby distinct from the natural sciences where cause-effect relationships prevail, it is based on mutual dependence between physician and patient in anticipation of acted-out or repressed expression of sentiments from both sides shaping the relationship. A further major idea extracted from Pareto's sociology related to the working of society as a whole rather than its components. Social systems were depicted in equilibrium, a state of mutual dependence between their constituent elements. If disequilibrium should occur, return to the state of equilibrium would promptly ensue. Henderson compared social equilibrium with physiological equilibrium, relating the former by analogy to 
the self-healing power of the living organism, and describing the latter through a vis medicatrix naturae which ensures recovery of the diseased organism even if no outside help should be available. Thus Henderson maintained that physiological equilibrium is logically identical with social equilibrium, and the latter may be understood by using examples illustrating the former (Henderson, 1935a, p. 46 et passim; Heyl, 1968, p. 326).

These ideas drawn from Pareto were later used by Parsons whose intellectual debt to Henderson is acknowledged in the preface of his Social System (1951a). But Parsons developed two further lines of thought during the 1930s which were to shape the sociological analysis of medical practice. First, he correctly claimed that his was a more physiological model of systems than Henderson's (who, after all, was a physiologist). Parsons' conception of equilibrium incorporates the idea of homeostasis derived from Walter B. Cannon's The Wisdom of the Body (1932). In this classic study, Cannon maintains that homeostasis is the hidden principle of life itself. The vast range of circumstances and stimuli which impinge upon the body are self-regulating. Body temperature, blood sugar and fluid contents of tissues remain remarkably constant and tend to return to their normal levels should temporary imbalances occur. Parsons used this idea but developed it into a four-phase balancing mechanism. In other words, Parsons derived from this physiological finding the idea of a social-control mechanism rectifying deviance through institutional and/or professional help.

The second issue where Parsons went beyond Henderson concerned the sociological analysis of the professions. His conceptual framework (outlined in 1939) identified medical practice not as an example of a social system but, rather, as one among four major professions representing partially non-economic but rational solutions of ongoing social problems: namely, medicine, technology, law and teaching (1939, p. 48).

Partly as an outcome of Henderson's staff seminar, by the end of the 1930s one major topic of medical sociology had surfaced in the academic interchanges between physiology and sociology at Harvard University. The analysis of medicine and medical practice as part of society's institutional and professional structure had yielded insights which would bring the analysis of medical care into the realm of sociological theory. The second major topic - namely, illness as deviance - had not yet taken shape. This would happen in the following decade of worldwide war and mass murder in Nazi concentration camps.

The connection between the political issues of the day and the medical perspective occasionally surfaced in the early 1940s, but it 
was not until the end of the Second World War - after knowledge of the holocaust had become widespread - that the question arose: can any member of a society be acknowledged as normal and sane if the society, simply by functioning, seems to rely on members who are far from normal and sane? In other words, deviancy and normality became foci of sociological attention because their boundaries had become blurred following recent historical events. Research in political psychology focusing on cognitive roots of Nazism showed that what had hitherto been regarded as utterly deviant (i.e., succumbing to Fascism or any anti-democratic regime) could be regarded as potentially normal. Millions of Americans were found to have attitudes congruent with latent Fascism. On the other hand, research into the mental make-up of Germans during and immediately after the Nazi period belaboured the point that the roots of the Fascist mind lay deeply entrenched in the institutions history and particular culture of the German nation. What did it mean if morally repugnant deviant acts became normal; if an entire society could be found guilty of gruesome crimes against humanity? In this situation the sociological endeavour was to re-establish the analytical boundaries between deviancy and normality. This laid the foundations of medical sociology as we know it.

Through this debate the notion of illness and its social control was formulated as part and parcel of sociological theory. In the very same year, 1951, Parsons' Social System and Edwin Lemert's Social Pathology were both published, each destined to become the cornerstone of one of the two main approaches in medical sociology.

As early as 1942 , in an article on the sociology of modern anti-Semitism, Parsons pointed out (if indirectly) that this was a psychiatric topic. Elaborately in a later article on mass aggression in the modern world (1947b), Parsons drew attention to unconscious aggressions propelling the anti-Semite to hate (if only in the muffled form of latent aggression). This would produce acquiescence with crimes against despised groups, by self-appointed 'revengers' (Gestapo) prosecuting publicly acclaimed scapegoats. Parsons hinted at psychiatry at the end of his article on antiSemitism when he dealt with the question of what was to be done: that is, looking at what he elsewhere called 'The Problem of Controlled Institutional Change' (1945). In 1942, he wrote:

The situation may be compared to that of a psychiatrist in treating a patient. The psychiatrist resorts neither to admonishment to 'be reasonable' nor to coercive measures, for he knows that this will do no good. What he does is to study the case from every angle; what he endeavors 


\section{xviii Introduction: The Origin of Medical Sociology}

is to understand the sources of the trouble. It is only then that he may find an effective cure for his patient . . . Similarly, anti-Semitism can be dealt with effectively only by fully apprehending all the problems involved in it. In other words, a rational policy towards anti-Semitism cannot consist in suppressing and punishing its expressions, but only in some analogous way in an attempt to control its deeper causes. Mere indignant repression of an evil is the treatment of symptoms, not of the disease. (1942a, pp. 121-2)

This passage is of tremendous interest. It conjectures that antiSemitism resembles a psychiatric disease two years prior to the 'Psychiatric Symposium on Anti-Semitism' which was held in San Francisco in 1944. This conference was the first forum for the ideas ventured by the group of researchers whose investigation into the psychological foundations of Fascism appeared in 1950 under the title of The Authoritarian Personality. All four major contributors to the research endeavour were present at the conference, plus such eminent scholars as Max Horkheimer who, in 1939, formulated the view that anti-Semitism was the epitome of the potentially Fascist and exploitative character of capitalist society in general. ${ }^{3}$ Various participants stressed the view that anti-Semitism was a psychiatric symptom not of the individual but of society. The issue was one of mass psychopathology which called for collective forms of overcoming 'anti-Semitism as an irrational mass phenomenon' (Simmel, 1946, p. 33). In the preface to the conference proceedings, psychoanalyst Ernst Simmel argued along lines remarkably similar to Parsons four years previously:

Anti-Semitism is irrational and since it dethrones reason as the regulating power in human interrelationships, it is bound to have a disintegrating effect on community life ... We proceed on the assumption that anti-Semitism must be a manifestation of a pathological mental process and that this process, under present economic and political conditions, leads to a decomposition of society and to the destruction of the anti-Semites themselves. Since it is obvious that the anti-Semitic concept of the Jew is clouded by a complex of persecution, antiSemitism requires investigation by the psychiatrist. General descriptive psychiatry, however, cannot clarify the problem. For this, the dynamic psychology of psychoanalysis must be employed. (1946, p. xix)

Accordingly, Freud's ideas on mass psychology were invoked, and controlled institutional change (or, to a certain extent, drastic political action bordering upon the revolutionary if necessary) was advocated. It promised to fulfil what Freud had expected from psychotherapy: namely, to convert some of the (collective unconscious) id into ego, and thus to submit the (societal) irrational 
partly to the control of rationality. These ideas were also in the background of the extensive empirical study investigating the attitude syndrome of Authoritarian Personality (Adorno et al., 1950). The latter was defined as a conglomerate of anti-Semitism, ethnocentrism, political-economic conservatism and latent Fascism, which were to depict a person's attitudinal propensity to vote and/or act in a way that conformed with any Fascist government or social environment.

One of the mechanisms characterising the person with an authoritarian personality structure was suggested as 'projection onto the body' of fears and anxieties. This showed a particular 'concern with physical symptoms' bordering upon 'hysterical conversions', especially in women. As proof of the significance for an authoritarian character structure of, for instance, putting emphasis on physical prowess or appearance, a number of interview excerpts were quoted:

F 71: Wouldn't like to be a nurse or M.D. - admires anyone who does, but 'I hate hospitals . . . I've been in so many; two mastoid operations and heart murmur. I have a great fear of doctors' offices. My heart has been giving me trouble so I go to the doctors for check-ups but haven't really been sick. Now I'm full of energy but they think it's nervous energy. I tire easily. I had scarlet fever when I was 10.'

M 45: 'Always sick, always going to the doctor.' (What was wrong with you?) 'Well, I don't think they ever knew.' (Adorno et al., 1950, pp. 459-60)

The striking issue about these statements growing out of the attempt to determine the structural relevance of anti-Semitism for modern society is that they focused upon topics, and used wordings, that were to become part and parcel of medical sociology which emerged during the ensuing years. The emphasis on psychoanalytic terminology describing the person's motivation to deviance is but one of the common characteristics of this literature as well as Parsons' ideas on aggressiveness and anti-Semitism. The same emphasis extends into early Parsonian medical sociology, and it reveals how strongly the latter was embedded in the explanations of Nazism focusing upon social prejudice as a disease. To a considerable degree, these ideas shaped the views on deviance outlined in Chapter 10 of The Social System.

By contrast, the second major starting-point of medical sociology, Lemert's Social Pathology, drew upon a considerably different background of ideas which had been circulating in American sociology since the early twentieth century. This second brand of theorising, if more indirectly, also raised the problem of how to 


\section{xx Introduction: The Origin of Medical Sociology}

explain political deviance sociologically; not just Nazism but any extremist view. Once again society rather than the individual was to be invoked as the agent of crime as well as its punishment (and the recurrence of crime through some agents of its institutional punishment), and as the origin of illness as well as its treatment (and the aggravation of illness through some forms of its institutional treatment). The main issues of this debate were discussed in a succession of six books (all bearing the same title of Social Pathology) published over a period of less than three decades (Queen and Mann, 1925; Mangold, 1932, with a second edition in 1934; Gillin, 1933, with a second edition in 1939, and a third in 1946; Queen and Gruener, 1940; Brown, 1942; Lemert, 1951). Lemert perceived the line of thought as explicitly anti-Freudian supporting this with a statement by the psychoanalyst Otto Rank as a protagonist of a 'new' non-psychological view of the deviant personality. Lemert stressed that he wished to endorse:

Rank's main criticism of the Freudian psychoanalysis . . . that it creates a sense of guilt over aggressive acts. By seeking to reeducate the client to 'adjust to' or 'accept' reality the Freudians deny the obviously aggressive, emergent, and creative nature of human society. From this point of view Freudianism is a disguised variety of ancient Hebrew conservatism. $(1951, \text { p. } 14)^{4}$

This view may contain a tinge of the anti-Semitism the overcoming of which had been the aim of the research on the authoritarian personality, and which had inspired the debates on controlled institutional change aimed at converting Nazi Germany into a future democratic nation. Lemert attempted a 'systematic theory of sociopathic behavior' which explicitly endorsed aggressiveness as not necessarily anti-social, and he chose to explain social facts through non-psychological processes producing rationality together with irrationality in society.

This endeavour was based on American sociology's concern since the early twentieth century with social problems and social science's capacity to mastermind social change which could act as a remedy for the ills of social disorganisation. Medical metaphors were widely used to characterise society's disintegration, and M. E. Richter's book on Social Diagnosis (1917) ${ }^{5}$ is said to have been influential. It in turn inspired the various monographs entitled Social Pathology (1925-51). The ideological side of these views was put in perspective by C. Wright Mills, who pointed out that they lacked a theoretically viable notion of social structure (1943). Moreover physical sickness as well as mental disease were but two 
of a catalogue of some 20 topics of individual or 'domesticrelationship' pathology comprising, for instance, blindness and deafness, drug addiction, alcoholism, suicide, divorce, illegitimacy, prostitution and old age. The general idea was that cultural relativism had come to prevail in American society, due to a breakdown of the social organisation (social order) in the wake of urbanisation and industrialisation, leaving individuals, groups and social classes deprived of the moral guidance which should have helped to avoid deviance. The optimistic general tone of this literature, and its liberal use of the medical metaphor, resulted from an optimistic persuasion, strengthened by the era of the New Deal, that social policy and the welfare state, together with an active community spirit, could solve the problems of modern society. The following statement from Frank's 'Society as the Patient' illustrates this:

Instead of thinking in terms of multiplicity of so-called social problems, each demanding special attention and a different remedy, we can view all of them as different symptoms of the same disease ... If, for example, we could regard crime, mental disorders, family disorganization, juvenile delinquency, prostitution and sex offences, and much that now passes as the result of pathological processes (e.g., gastric ulcers) as evidence, not of individual wickedness, incompetence, perversity, or pathology, but as human reactions to cultural disintegration, a forward step would be taken. (Frank, 1936, p. 336)

The sociological theory embedded in the literature on social pathology amounted to scarce references to C. H. Cooley (1902, $1909,1918)$. His widely cited view that socialisation, the influences of groups upon the individual's attitudes and beliefs, was the key to understanding deviant social actions became generally adopted. Lemert relied heavily on the list of social problems dealt with in the previous books on Social Pathology: each of these had set out to unite the various forms of deviance under a common explanatory perspective. He added to the scope of solutions offered by the literature only a seemingly minor idea. Realising that Cooley's theoretical conjecture of 'looking-glass self' was but the forerunner of George Herbert Mead's idea that significant others, and symbolic meaning, shaped the structure of selves in interaction, he based his interpretation of the origin and prospects of deviance on Mead's idea of symbolic mediation.

It seems ironic that the pragmatism which pervaded much of American social science for a good half-century should have been all too readily discarded in the wake of the Second World War. 


\section{xxii Introduction: The Origin of Medical Sociology}

Today Lemert's book, which draws heavily on the then wellestablished perspective of social pathology, is regarded as an original work beyond its genuinely novel contribution. This only documents how much the Second World War acted as a watershed of ideas which shaped the sociological endeavour. This may be no coincidence; rather, it may represent a historically logical achievement that the two books which 'started' medical sociology were but reformulations of topics entrenched in the two main lines of thought prevailing immediately after the Second World War. While Lemert's Social Pathology was embedded in the longstanding tradition of pragmatism in American social thought, Parsons' Social System introduced novel elements of psychoanalytic thinking which had only recently become respectable in social science. The latter had proved their usefulness through explaining as deviance not only drug addiction and juvenile delinquency, but also mass murder and the asquiescence to it.

During the $1950 \mathrm{~s}$, medical sociology made rapid progress. At the end of the decade, it had already become a section of the American Sociological Association. Like most other subspecialties which developed after the Second World War, sociology analysing the structure in or of medicine (Straus, 1957) spread from the US to various European and non-European countries where, in turn, prospering sections of national Sociological Associations developed. For instance, the Medical Sociology Group of the British Sociological Association held its first annual conference at York in 1964; in Germany, it was only in 1972 that the section of the Deutsche Gesellschaft für Soziologie was established, but in the same year the German Society for Medical Sociology was founded and its membership is now one-fifth of that of the German Sociological Association. Today, medical sociology represents a respected field of knowledge in most countries outside the Eastern bloc. The European Society of Medical Sociology was founded in 1983 while the International Sociological Association established its Research Committee 15 in 1966 (named 'Medical Sociology' but known since 1986 as the 'Sociology of Health').

In spite of successfully becoming a part of the sociological endeavour, and being incorporated into medical education in many countries, medical sociology has found itself unable to achieve the unity of analytical perspective which is thought to be an indispensable prerequisite if acknowledgment is to be won from the medical profession. Medical sociology often regrets not presenting a cohesive picture. It mirrors the diversity of theoretical approaches which has characterised sociology since its inception in the nineteenth century. This may not be a disadvantage, however. 
If social science is to be different from natural science in taking account of the fact that its subject area concerns human beings who more or less consciously engage in social action, rather than nature morte where general laws invariably apply, medical sociology might as well be proud that it lacks the unity of perspective which many of its protagonists seem to want.

However, it is also true that little comparative work has been done so far which would make explicit the different theoretical views in medical sociology. It is far from clear how they relate to the main approaches of the 'mother discipline' in general. ${ }^{6}$ Since most authors are content with propagating one view which is more or less adequately derived from one of the major theoretical perspectives or 'grand theories', often a degree of eclecticism is reached in their definition and use of concepts that may sometimes be unsatisfactory. In order to counteract this, a comprehensive overview seems to be needed of the history and main ideas of medical sociology, and how they relate to mainstream sociology.

The development of medical sociology can be separated into four phases each introducing aetiology, therapy and organisation of medical care under one of the major sociological paradigms. The earliest conceptualisation - which received widespread acclaim and, in fact, became the only acknowledged approach in the 1950 s - was that of Parsons, supplemented by other structural functionalist views. Soon after publishing the Social System Parsons, together with Renée Fox, published on the topic of family, therapy and illness (1952). Fox also contributed to research at Columbia University focusing on the Student Physician and how students learn to practise medicine (Merton et al., 1957). During the early 1950 s, Parsons continued to illustrate his general theoretical points using medicine and, in particular, sickness as examples (Parsons, Shils and Bales, 1953). After this time, he wrote on special aspects of the health-and-illness topic, and in 1964 included some of this work in a collection of essays, introducing the organic as a fourth system beside the cultural, social and the psychological. However, by that time medical sociology had not only become a fast-growing subspecialty but was also rife with conflict regarding the question of whether structural functionalism was the right approach. The heyday of systems theory was long over, and it has never been restored to the hegemonic role which it played in the 1950s. Indeed, so widespread became the tendency to 'overcome' and 'supersede' Parsons, and structural functionalism in general, that not only were later contributions to medical sociology by Parsons hardly noticed, but even those colleagues who today follow him are often unaware of the heritage. 


\section{xxiv Introduction: The Origin of Medical Sociology}

Structural functionalism was eventually toppled by Goffman's introduction in 1959/61 of a situational-analysis approach. This owed little to systems theory but everything, albeit unconsciously, to Georg Simmel. Without giving credit, it also relied heavily on Lemert's recognition of the relationship between symbolic meaning construction, stigmatisation and deviance. During the decade, authors like Howard Becker, Everett Hughes and Anselm Strauss had begun to develop a view upon drug addiction and other 'classic' forms of deviance which was indebted to G. H. Mead's ideas on the links between mind, self and society. In fact these authors, together with Julius Roth, Fred Davis, and Rue Bucher (except Hughes who was a professor) belonged to a cohort of graduate students at Chicago University where G. H. Mead's interactionist perspective had been kept alive after his death in 1931. Despite this ongoing work it was only the political thrust of Goffman's compassionate account on the plight of prison inmates and patients in mental hospitals which caused the breakthrough of 'symbolic interactionism' at the start of the 1960s. Already Dahrendorf's acid comparison (1958a) between the Utopia hidden behind Parsons' Social System and Aldous Huxley's Brave New World (1932) had prepared the ground for abandoning structural functionalism as the one and only acclaimed theoretical perspective. At this strategic point, Goffman's books turned the tables. The 1960s emerged as an era of 'labelling theory' in general and medical sociology in particular. From then, the debate continues whether and to what extent medicine represents a political endeavour. The definition of what constitutes illness or health is itself said to be far from politically neutral.

As noted above, Parsons' views in Chapter 10 of the Social System owe much to the intellectual shock of Nazism. It became disconcertingly clear that what constituted health, as a collective if not an individual mental state, seemed largely determined by social definitions of normality. Among others, Parsons made attempts to neutralise the threat of political definitions of normality in the early 1950s. In pointing out that the sociologically relevant aspect of health or illness would always be connected with mental aberrations, mass neurosis could be acknowledged and seemingly demystified. Furthermore, by identifying the 'power' of the doctor as professional expertise, which precluded exploitation and domination, Parsons offered the assurance that dangerous political aspects of medicine were contained within the norms and values of society. If this quenched the debate during the 1950s, the topic came back with a vengeance in the early 1960s. The selfrighteousness of structural functionalism was rightly questioned 
and effectively shaken. Becker, in particular, reasserted the view that deviance was all but political, retrospectively claiming Lemert as the chief witness for his argument. In Outsiders (1963), a collecton of earlier essays which now became widely read,he maintained that Lemert's thesis had been political all along. In essence, Becker identified the political implications of Lemert's thesis on the cultural relativity of standards of health and normality, implications Lemert had failed to recognise.

As the debate on the 'NeoChicagoans' (Matza, 1969) continued unabated throughout the 1960s, a third theoretical approach emerged within sociology. For a period, phenomenology epitomised the source of radical or maverick views. Medical topics stood at the cradle of ethnomethodology even before Harold Garfinkel in 1967 phrased the book title which gave the name to the approach. When and how a suicide verdict is reached, what happens when a patient gets away with self-induced change of gender in spite of medical supervision monitoring that no artificial hormones are involved, how mental illness is a collective achievement of mutual behavioural practices between patient and professional in treatment institutions, were but a few topics of interest which preceded the publication of (and were included in) Garfinkel's Studies in Ethnomethodology (1967a). But in spite of the havoc created by the rise to short-lived fame of this seemingly untenable and allegedly all-pervasive theoretical approach, it never managed in medical sociology to receive as widespread an acclaim as other analytical perspectives. Nevertheless, ethnomethodology (including Cicourel's splinter Cognitive Sociology) has continued to make valuable contributions to medical sociology. Some of its most useful ideas regarding medical practice were possibly elaborated in England and Germany in the early 1970s. Recently, its focus has shifted to language structures in multiple treatment settings where promising links with sociolinguistics have developed.

The fourth and last addition to the theoretical scope of medical sociology originated partly in the ranks of the Marxists. In 1968, as students in the US, France and Germany plunged into what was prematurely considered as a revolution, medical sociologists began to realise that injustice and inequality were legitimate topics for academic enquiry. Two main directions emerged: on the one hand, medicine was identified as an institution of social control proliferating in modern society such that there was an increasing tendency to 'medicalise' whole areas of everyday life. This view, angrily stated by authors like Zola and McKinlay just after 1970, was loosely connected to the general belief that poverty and deprivation are an outcome of power and prejudice. In the middle 
1970s, Illich's rabid criticism of 'medical nemesis' (1975a) owed much to this perspective (at least in how and by whom it was received), elaborating the view that through its very growth and improvement as a technical endeavour, modern medicine created iatrogenic disease and even death to a hitherto unthinkable extent. In its more recent form, this argument holds in equally radical fashion that diagnostic categories, and even the notion of illness, were but repercussions of repressive life circumstances in various periods of history including the present. The issue is debated whether the views collected, for instance, in Wright and Treacher's The Problem of Medical Knowledge (1982) represent relativism. The incorporation of Foucault's work into medical sociology might denote an offshoot of symbolic interactionism, or a genuinely new view on the social roots of medicine.

The second line of argument focuses on the individual's experience of illness. It aims at proving through research that the social origin of mental as well as physical illness is loss produced by life circumstances. In this, a mildly radical tendency is combined with the view that self-help might serve the patient equally as well as professional help. The view has sprung up since the early 1970s that discrepancies between person and environment influence health negatively. This has drawn into sociology the stress model which originates in a strictly medical framework.

In this, the political aspect of the health-illness division and of medical endeavours again occupies the forefront of interest. The political motive derives from disadvantage and deprivation in modern mass society making for increased premature mortality rates of the lowest-income strata. The general theory relating to this is one of social conflict.

These four paradigms - namely, Parsons' key perspective within structural functionalism, symbolic interactionism merging with socalled labelling theory, ethnomethodology as the core perspective within phenomenological sociology, and the self-styled Marxist view which has been supplemented by a non-Marxist model to represent a conflict-theory approach - have become the cornerstones of the theoretical foundations of medical sociology. The latest of these approaches was introduced in the 1970s. Since then, no further paradigm has been outlined which claims thoroughly to reform the theoretical foundations of medical sociology. Although recently Foucault's work has been used with this aim, it refines the conflict paradigm's idea of power and knowledge rather than representing a new approach in its own right. During the last ten years, all paradigms continued to be used, if only in the guise of widespread concepts (such as, for instance, sick role or stigma) 
seemingly with no origin in general theory. It seems appropriate to look back and take stock of where we stand. What are the current as well as the permanent problems regarding the conceptualisation of illness as part of sociology?

In the four parts that follow a systematic format has been adopted. The presentation of each of the four paradigms will comprise four steps of reconstruction.

1. A general outline of each theory's notion of illness will be presented. This includes a short account of what each paradigm considers as political in the definition of illness. Mostly, this relates to the issue of cultural relativity, on the one hand, and economic connotations of health which determine one's work strength and, hence, earning capacity in modern industrial society on the other. The basic theoretical argument usually also contains a justification of why sociology finds in medical issues a legitimate topic, though its own reasoning is nonmedical.

2. Illness must be elaborated to incorporate some notion of causality. Conceptualisations of the origin and aetiology of disease, illness or sickness are a major part of the sociological effort in medicine. Of particular interest in this book is how these conceptualisations use the perspectives from wider frames of sociological theory, namely, structural functionalism, interactionism, phenomenology and conflict theory (Marxism). Each paradigm makes an independent endeavour to understand illness, and to make plausible how the aetiology may be understood as a social process rather than, or supplementary to, a medical one.

3. This leads to the issue of treatment. Aetiology and treatment appear as two consecutive phases, the former explaining emergence, the latter dealing with management and recovery. It is interesting that the analysis of treatment needs to follow the same principle as that of aetiology such that the two form phases of a process. It is a matter of definition, however, whether the social element of the treatment side of illness would be perceived as predominantly one of institutional care or, rather, one of individual experience. Both views, to be sure, have their counterparts in conceptualisations of aetiology.

4. These accounts only fall into place if the book succeeds in making clear the illness explanations' theoretical viability. For instance, what is it that is structural functionalist about Parsons' ideas on illness? Are they an example of 'true' systems theory, particularly in view of the fact that psychoanalysis plays a major 
part in Parsons' medical sociology (i.e., the sociology of deviance) while at least not openly shaping his general sociology? Do the sometimes odd explanations of labelling theory hold water under the broader auspices of 'symbolic interactionism' as grounded in G. H. Mead's work? Do the concepts used to conduct research under an ethnomethodological (including conversational-analysis and 'cognitive sociology') point of view, fit into the lines of the 'classic' argument drawn out in the late 1960s? And does, for instance, Goldthorpe's criticism that its epistemological position is untenable (1973) undo the credulity of the phenomenological approach in general? Last but not least, would conflict theory in medical sociology, whether or not an offshoot of modern Marxism, necessarily come to endorse critical views on society? Is there a clear linkage between the more health-concerned writings on the welfare services and the more economic writings such as, for instance, O'Connor's The Fiscal Crisis of the State (1973), or would there be a gap between medical sociology and its more materialistic counterparts? Therefore the final part of each chapter will draw a line between each viewpoint outlining the social side of illness and medicine, and the general idea of what social action is meant to be; that is, how the latter squares with illness and the doctor's task as well as the generalised notion of society. In this, to be sure, the stance of each of the four paradigms on the idea of 'sick society' matters. It is here that the problem of antiSemitism helps to highlight the conjectures regarding the general nature of the social order.

As it happens, nearly all theoretical paradigms when used in empirical research seem to be broken down into various specific views. These often appear so diverse that it seems hardly feasible to piece them together into a comprehensive picture of each original theoretical perspective. The theoretical paradigms of structural functionalism and symbolic interactionism divide into two more or less independent models which nevertheless maintain a certain degree of unity. The conflict-theory paradigm may be separated into two or three different models. But since no attempt has been made so far to draw these writings together under their explanatory perspective, two models will be outlined, the second one a conglomerate of approaches which could be subdivided into Marxist and non-Marxist. Phenomenology only presents one model so far, but a second one is emerging. In essence, it is through research that the viability of a theoretical endeavour must prove itself, which also affects the number and scope of explanat- 
ory models contained in a theoretical paradigm. It is here that progress takes place in the development of medical sociology.

I hope that the reader will bear with me exploring the meanders of arguments and counter-arguments. Medical sociology, in my view, is more than a casual offshoot of social science in the age of proliferation of subdisciplines. I am confident that this book provides enough evidence for the reader to feel able to corroborate or refute the claim that medical sociology is to be considered the legitimate offspring, if not a vital part, of what has come to be named general sociology. 